\title{
IDENTIFICATION OF BURNED AREAS BY SPECIAL INDEX IN A CERRADO REGION OF THE STATE OF TOCANTINS, BRAZIL
}

\author{
Ingridy Mikaelly Sousa Pereira ${ }^{1}$, Edmar Vinicius de Carvalho ${ }^{1}$, Antônio Carlos Batista ${ }^{2}$, Igor Eloi Silva \\ Machado $^{2}$, Maira Elisa Ferreira Tavares ${ }^{1}$, Marcos Giongo $^{1 *}$ \\ ${ }^{1 *}$ Federal University of Tocantins, Center for Environmental Monitoring and Fire Management, Gurupi, Tocantins, Brazil - \\ ingridymikaelly@uft.edu.br; carvalho.ev@uft.edu.br; mairaelysa@hotmail.com; *giongo@uft.edu.br \\ ${ }^{2}$ Federal University of Paraná, Department of Forestry, Curitiba, Paraná, Brazil - \\ batistaufpr@gmail.com; igeloi@hotmail.com \\ Received for publication: 10/01/2018 - Accepted for publication: 04/05/2018
}

\begin{abstract}
Obtaining information on burned areas has been studied and improved in the last decades, and the biggest question is the acquisition of consistent and detailed information about the occurrence of burnings in a simple and effective way. In view of this, remote sensing is a very interesting tool because it allows obtaining information in large areas of difficult access. The identification of areas burned by orbital data is directly related to their spectral behavior. The objective of this study was to analyze the performance of spectral indices in the identification of burned area in OLI/Landsat- 8 satellite images. The indices for the before and after fire images were calculated using bands of red and near infrared: NDVI, MSAVI, SAVI, and GEMI, and bands of near infrared and short wave infrared: NBR, BAIMmod, and MIRBImod. The difference between pre and post-fire index was also calculated: dNDVI, dMSAVI, dSAVI, dGEMI, dNBR, dBAIMmod, and dMIRBImod. From these indices, six different compositions (RGB) were created and later they were segmented and classified in a non-supervised way and soon after made the extraction of the area of interest. The results of this classification were validated with the reference data obtained through the visual interpretation of the image. The methods had shown a good quality of classification, with a percentage of accuracy ranging from 85.54 to $92.46 \%$ and Kappa value of 0.70 to 0.89 . The best method was the dNBR, NBRpost-fire, and dMIRBImod indices in the RGB composite.
\end{abstract}

Keywords: Fire, spectral behavior, orbital data.

\section{Resumo}

Identificação de áreas queimadas por meio de índices espectrais em região do cerrado tocantinense A obtenção de informações sobre área queimada vem sendo bastante estudada e aprimorada nas últimas décadas, sendo a grande questão baseada na aquisição de dados consistentes e detalhados sobre a ocorrência de queimadas de forma simples e eficaz. Diante disso, o sensoriamento remoto se apresenta como uma ferramenta de grande interesse, pois possibilita obter informações em áreas extensas e de difícil acesso, com a identificação das áreas queimadas, possível pelo seu comportamento espectral. Neste trabalho, objetivou-se analisar o desempenho de índices espectrais na identificação de área queimada em imagens do satélite OLI/Landsat-8. Para isso, foram calculados os índices nas imagens antes e depois do fogo, que utilizaram as bandas do vermelho e do infravermelho próximo: NDVI, MSAVI, SAVI, e GEMI; e as bandas do infravermelho próximo e do infravermelho de ondas curtas: NBR, BAIMmod, e MIRBImod. Além disso, foi calculada a diferença entre cada índice pré e pós-fogo: dNDVI, dMSAVI, dSAVI, dGEMI, dNBR, dBAIMmod, e dMIRBImod. A partir desses índices, foram criadas seis diferentes composições (RGB), que foram, posteriormente, segmentadas e classificadas de forma não supervisionada e logo após a extração da área de interesse. Os resultados dessa classificação foram validados com os dados de referência, obtidos através da interpretação visual de imagem. Os métodos apresentaram valores ótimos a excelentes quanto à qualidade da classificação, com porcentagem de acerto de $85,54 \%$ a $92,46 \%$ e valor Kappa de 0,70 a 0,89. O melhor método foi composto pelos índices dNBR, NBRpós-fogo e dMIRBImod.

Palavras-chave: Fogo, comportamento espectral, dados orbitais.

\section{INTRODUCTION}

Satellites capture information from earth's surface through sensors with data available in the form of orbital images. Thus, they represent a tool of high value due to the possibility of obtaining information in large areas of difficult access (BOSCHETTI et al., 2010). The use of remote sensing has been very useful and effective in the estimation of areas affected by fire, as well as in the evaluation and monitoring of forest fires at different scales (LHERMITTE et al., 2011; SANTOS et al., 2018). Its use enables the advancement of studies on the dynamics of forest fires by monitoring changes in the surface.

FLORESTA, Curitiba, PR, v. 48, n. 4, p. 553-562, out/dez. 2018

Pereira. I. M. S. et.al.

ISSN eletrônico 1982-4688

DOI: $10.5380 /$ rf.v48i4.57362 
The identification of burned areas from remote sensing is based on the analysis of their spectral behavior. After the action of the fire, it is possible to observe changes the influence the spectral response, which are ash and coal deposition; regrowth; and reduction or removal of vegetation (BOSCHETTI et al., 2010). Each of these features a reflectance value in the range of the electromagnetic spectrum.

According to Garofalo et al. (2015) and Li et al. (2017), the classification of images, i.e., the extraction of information, can be done by several methods - digital analysis, quick retrieval, and visual, more laborious, analysis. These forms of analysis can bring solutions to digital methods, regarding the best results obtained by the human visual system. Nevertheless, there are still several gaps and limitations to be filled, in addition to the lack of data that describe in detail the occurrence of the fire in an area of interest. Therefore, burned area mapping remains an active topic in research involving remote sensing (STROPPIANA et al., 2012).

The unsupervised classification of images is quite efficient in extracting information from satellite images. In this process, it is possible to use algorithms to recognize the classes within a data set that considers the spectral characteristics of the pixel and groups them according to the values present in each one (GAROFALO et al., 2015). An important point in this process is the use of easy-to-obtain spectral indices, which have good performance, provide a reduction in processing time, and eliminate subjectivity in the discrimination of fire-affected areas (VERAVERBEKE et al., 2012). Fire mapping studies using spectral indices show that the Normalized Burned Ratio (NBR), which attempts to maximize the reflectance change due to fire, stands out in the expected objective, even though the Soil Adjusted Vegetation Index (SAVI) has greater overall accuracy in the delineation of burned versus unburned areas (NORTON et al., 2009).

It is worth mentioning that these spectral indices are sensitive to changes in different physiognomies, as they result from mathematical expressions that use reflectance values (PEREIRA et al., 2016). For example, the Normalized Difference Vegetation Index (NDVI) is sensitive to vegetation chlorophyll or absence of vegetation in the case of burned areas, being widely used because it is obtained simply (STROPPIANA et al., 2012). In addition, regarding the procedure of difference on bi-temporal images (pre and post-fire), the NDVI is also widely adopted, including for spectral indices, based on the detailed choice of pre-fire images that best emphasize the features of the burned-area (CARVALHO-JÚNIOR et al., 2015).

In the Cerrado, fire can occur naturally, since it is part of the ecology of this biome. However, increasing frequency and recurrence of fire in this region change forests and cause disturbances in ecosystem ecology (PEREIRA et al., 2016). Anthropic practices result in increased susceptibility to fire occurrence in these areas, due to intensive soil management in the Cerrado region, which has a well-defined dry season and susceptibility to fire occurrence.

In this context, based on the hypothesis that it is possible to detect burn scars through spectral indices, this study aims to evaluate the performance of these parameters in the identification of burn scars. This research will be carried out through a temporal analysis of the images from OLI/Landsat- 8 satellite in the Cerrado region of the state of Tocantins, Brazil.

\section{MATERIAL AND METHODS}

\section{Area of study}

The area of study is located in the orbit/point 221/68, between the coordinates $10^{\circ} 52^{\prime} 50^{\prime \prime}-$ $12^{\circ} 23^{\prime} 50^{\prime \prime} \mathrm{S}$ and $47^{\circ} 37^{\prime} 20^{\prime \prime}-46^{\circ} 05^{\prime} 20^{\prime \prime} \mathrm{W}$, and covers an area of 1,267,913.78 hectares, covering the municipalities of Almas, Dianópolis, Novo Jardim, Ponte Alta do Bom Jesus, Porto Alegre do Tocantins, Rio da Conceição and Taipas do Tocantins. This region covers about $11 \%$ of the Serra Geral do Tocantins Ecological Station (ESCEC) and 35\% of the Serra da Mombuca Environmental Protection Area (APA). In addition, it contains the priority area for implementation of a conservation unit of the Vale do Rio das Palmeiras (valley).

In this context, the average annual precipitation is around $1,600 \mathrm{~mm}$ and the average air temperature around $26^{\circ} \mathrm{C}$. The climate is characterized, according to Thornthwaite's classification, as C2w2A'a', humid sub humid climate, with small water deficiency, potential annual evapotranspiration of 1,600 mm (distributing, in summer, around $410 \mathrm{~mm}$ over the three consecutive months with higher temperature). The vegetation is composed almost completely of savanna formations that include rupestrian field, vereda, Cerrado sensu stricto, park of Cerrado, and Cerradão.

\section{Acquisition and preprocessing of images}

For the performance of this study, we used two sensor images from Operational Land Imager (OLI) on board the satellite Landsat- 8 , with 30 meters of spatial resolution. The images refer to the orbit/point 221/68 on the dates of July 19, 2016 (pre-fire) and September 7, 2016 (post-fire). The acquisition took place through the database United State Geological Survey (USGS). 
Initially, the image was converted into radiance values, based on parameters from the metadata file provided by the USGS. Then, the atmospheric correction was performed with the aid of the algorithm FLAASH, which uses the radiative transfer code MODTRAN. This correction was performed to minimize the effects of the atmosphere on the image and to put the data in the same scale (CARVALHO et al., 2017), since these effects affect reflected radiance (MOSES et al., 2012).

\section{Image processing}

Semiautomatic methodology

In order to obtain the burned area by means of the semiautomatic methodology, the image processing was divided into three phases (Figure 1).

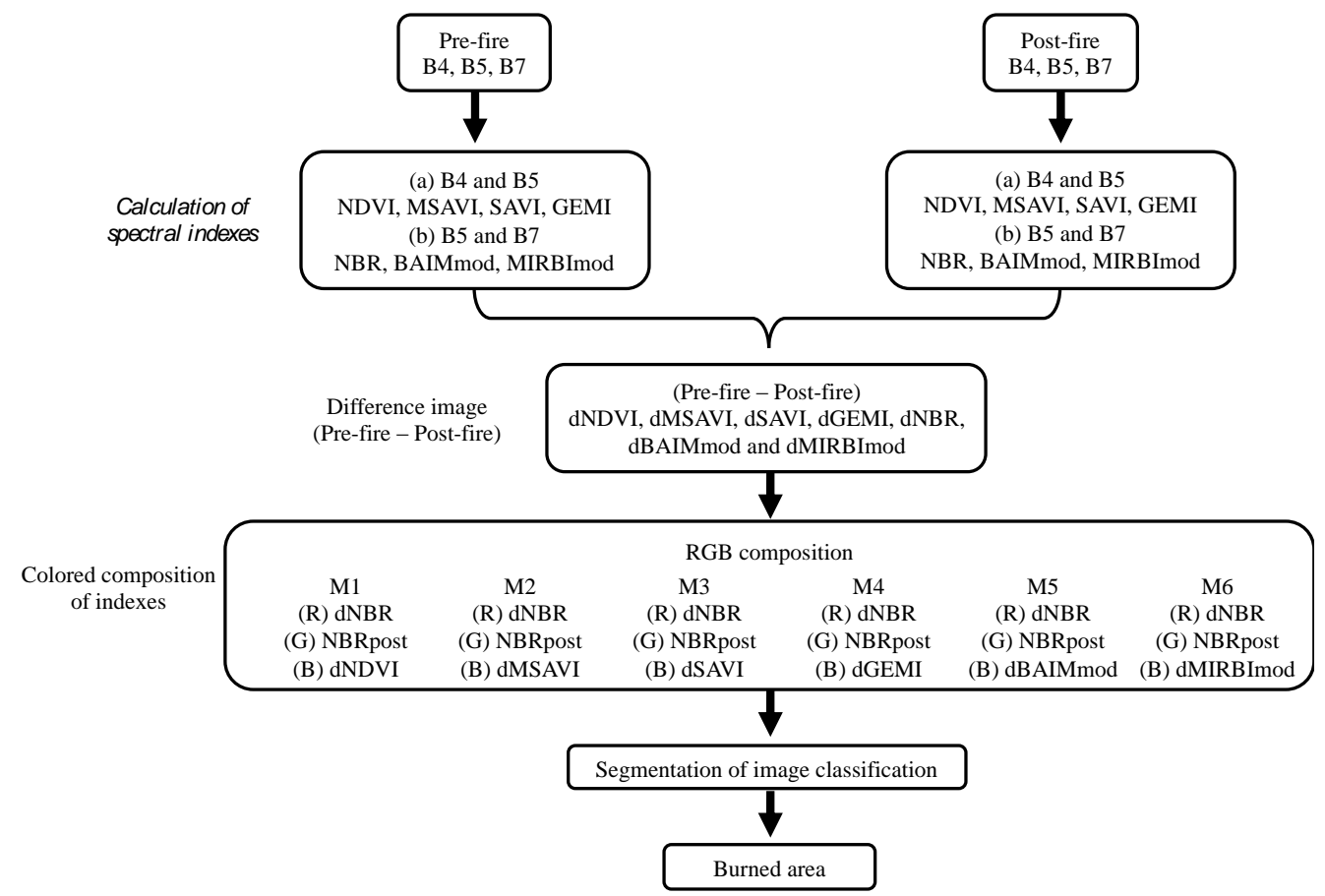

Figure 1. Flowchart of the semiautomatic methodology.

Figura 1. Fluxograma da metodologia semiautomática.

Calculation of spectral indices

The first phase consisted of the calculation of the spectral indices most used in the literature for the discrimination of burned areas. These indices were divided into two groups according to the combination of bands used, and calculated based on the equations described in Bastarrika et al. (2011) and Xue and Su (2017): (a) indices that use the combination of band 4 (red) + band 5 (near infrared) - NDVI, MSAVI, SAVI, and GEMI; (b) indices that use the combination of band 5 (near infrared) + band 7 (shortwave infrared) - NBR, BAIMmod, and MIRBImod. The last two indices were modified for this study by altering the original equations of the indices BAIM and MIRBI, respectively.

Thus, the seven indices were calculated for the pre-fire image (June 2016) and for the post-fire image (September 2016). Afterwards, we obtained the difference image for each index through the operation between the two images: dNDVI, dMSAVI, dSAVI, dGEMI, dNBR, dBAIMmod, and dMIRBImod, in order to attain information on the changes occurred in the period analyzed.

Colored composition of indices

In the second stage of the study, we carried out the production of colored compositions (RGB). These compositions were made through combinations among the spectral indices generated. The study aimed to highlight the areas affected by fire and thus facilitate the next process of segmentation and classification, since, from this method, the scars of burnings occurred in a certain period are detached from other features that may have characteristics similar to those of burnings. Owing to the fact that it is a temporal analysis, the color composition presents characteristics as a function of the variation that occurred in the considered period. Thus, 
the most constant targets over time, such as water bodies and exposed soil areas, are distinct from burn scars because they result from abrupt changes in vegetation greenness (CÂNDIDO, 2014).

We made six RGB compositions from the indices generated, using six different methods to obtain burned area. The combinations were based on the research done by Cândido (2014), which used this type of composition with indices to highlight the areas affected by fire, especially the color composition with the NBR index in the red channel (R), dNBR in the green (G) and dNDVI in blue (B). Hence, based on this combination and on tests performed with the indices generated during image processing, the formation of the compositions was standardized using dNBR in the channel R, NBRpost in G-channel, and each index in B-channel resulting from the pre and post-fire.

\section{Segmentation of image classification}

In the third stage, we performed the segmentation and classification of the colored composition submitted to the algorithm of segmentation Mean Shift. This unsupervised method performs groupings by regions, according to the mean value of the pixels, for which they have established thresholds values for image segmentation.

The segmented image underwent a training phase in which we took samples from the present classes. For this purpose, we established three classes: (1) burned; (2) unburned; and (3) vegetation. These samples were used in the following unsupervised classification process using the algorithm Classification Maximum Likehood, which distributed the image in the classes defined above. Therefore, it was possible to extract the class of interest for the study (burned area).

Subsequently, this image was converted into vector file to obtain the following information: size of the burned area; classification of the burned area (I < 25 ha; II: 25.01 to 100 ha; III: 100.01 to 1600 ha; IR > 1600 ha); and number of polygons. Finally, we performed the intersection of the polygons obtained by the segmentation that manually generated polygons (reference methodology).

\section{Reference methodology}

The visual interpretation of burn scars was the form used to obtain data during the study. This interpretation is a technique traditionally used to detect burned areas. Although it is a time-consuming process, the strategy is considered relatively simple and allows obtaining reliable results. Generally, the data obtained are used to validate and evaluate the accuracy of burned area algorithms, as observed in the study of Bastarrika et al. (2014).

In order to delimit the scars present in the image of September 7, 2016, we used the RGB color composition formed by bands 7 (short-wave infrared), 5 (near infrared), and 4 (red), respectively. From this composition, it was possible to identify the burned areas and distinguish them from similar targets, precisely by highlighting the area that was hit by fire. Such information generated through this methodology related to burned area was also associated to the classes of soil coverage and use, from the region studied. It was made available as vector file by the Center for Environmental Monitoring and Fire Management (CeMAF). We did likewise in relation to the burned area verified by each method described above.

\section{Accuracy analysis}

To measure the accuracy of the methods, we calculated the Kappa index, which was used to evaluate the proximity between the reference and the other methods tested (CARVALHO-JÚNIOR et al., 2015). We obtained this index through a confusion matrix generated by the comparison of the reference data, considered as "ground truth", in relation to the data generated by the semi-automatic classification. We made this matrix from the allocation of points systematically in the study area with the burn scars polygons, which we later classified as coincident or not with the polygons affected by the fire that each method has detected. In this sense, it was assigned 0 for unburned area and 1 for burned area.

In addition, such a confusion matrix enabled the calculation of errors of omission and commission of the methodologies evaluated. According to Kumar and Roy (2018) and Healey et al. (2018), on the one hand, errors of omission refer to areas where the reference methodology identified a burn scar that other methodologies have omitted. Errors of commission, on the other hand, refer to areas that have been identified by the methods under test and that do not correspond to a scar in the reference methodology.

\section{RESULTS}

From the segmentation and classification of each colored composition made from the combination of the spectral indices, it was possible to obtain the total extension of the burned area of the study for September 2016. Table 1 shows the amount of burned area each methodology detected, along with their respective percentage of accuracy. This percentage was achieved through the intersection between the polygons of the 
reference methodology and the polygons obtained by the methods analyzed. Table 1 also presents the errors of omission and commission, as well as the Kappa index.

Table 1. Burned area (in ha) detected by each method, accuracy percentage of each method in relation to the reference, omission and commission errors, and Kappa index.

Tabela 1. Área queimada (em ha) detectada por cada método, porcentagem de acerto de cada método em relação à referência, erros de omissão e comissão e índice Kappa.

\begin{tabular}{cccccc}
\hline Method & BN (ha) & Success (\%) & CO (\%) & OM (\%) & Kappa \\
\hline Reference & $128,351.50$ & - & - & - & - \\
\hline M1 & $162,859.98$ & 90.60 & 9.40 & 28.60 & 0.86 \\
M2 & $151,468.06$ & 91.85 & 8.15 & 22.17 & 0.88 \\
M3 & $179,232.27$ & 92.46 & 7.54 & 33.79 & 0.85 \\
M4 & $159,275.99$ & 90.30 & 9.70 & 27.23 & 0.85 \\
M5 & $165,334.79$ & 85.54 & 14.46 & 33.59 & 0.70 \\
M6 & $154,588.63$ & 92.41 & 7.59 & 23.27 & 0.89 \\
\hline
\end{tabular}

M1: (R) dNBR (G) NBRpost (B) dNDVI; M2: (R) dNBR (G) NBRpost (B) dMSAVI; M3: (R) dNBR (G) NBRpost (B) dSAVI; M4: (R) dNBR (G) NBRpost (B) dGEMI; M5: (R) dNBR (G) NBRpost (B) dBAIMmod; M6: (R) dNBR (G) NBRpost (B) dMIRBImod; BN (ha): burend areas that have been identified by each methods. Success $(\%)$ : percentage of areas that have been identified by the methods under test and reference methodology. CO (\%): commission errors OM (\%): omission errors; e Kappa: index for evaluate the accuracy of the methods.

In this context, the reference methodology, which was obtained through visual interpretation of images and manual delimitation of the scars, quantified 128,351.50 hectares of burned area in the study region for the image of September 2016. These data were used in the validation and in the comparison carried out with the methods tested.

In relation to the burned area identified by other methods, the surface varied from 151,468.06 to $179,232.27$ hectares, which were obtained by methods 2 (dNBR, NBRpost, dMSAVI) and 3 (dNBR, NBRpost, dSAVI), respectively. Both methods used the red and near-infrared bands. Regarding the accuracy percentage of the methods tested, which was obtained through their intersections with the reference methodology, there was an accuracy rate of $85.54 \%$ to $92.46 \%$, registered by methods 5 (dNBR, NBRpost, dBAIMmod) and 3 (dNBR, NBRpost, dSAVI), respectively. It is worth noting that this result demonstrates the methods' ability to correctly delimit the burn scars.

Thus, errors of commission varied from 7.54 to $14.46 \%$ when identified by methods 3 (dNBR, NBRpost, dSAVI) and 5 (dNBR, NBRpost, dBAIMmod), respectively, while errors of omission varied from 22.17 to $33.79 \%$ when identified by methods 2 (dNBR, NBRpost, dMSAVI) and 3 (dNBR, NBRpost, dSAVI). Regarding the accuracy percentage, method 3 in addition to presenting a higher accuracy rate also presented a lower rate of commission errors.

Furthermore, the Kappa value was calculated for each method in order to measure its accuracy. It was possible to observe a variation from 0.70 to 0.89 , obtained by methods 5 (dNBR, NBRpost, dBAIMmod) and 6 (dNBR, NBRpost, dMIRBImod), respectively. The variation was rated from very good to excellent.

Moreover, the scars in the observed areas were divided into size classes (Table 2), in order to assess the influence of the size of the burns on the detection process. For this, spectral indices were used. Based on this, we sought to understand the influence of the size of the burned areas on the chances of these areas being detected due to the spatial resolution of the sensors used and/or the low energy emitted in these events.

Table 2. Number of polygons and corresponding area distributed by size classes.

Tabela 2. Número de polígonos e área correspondente distribuídos por classes de tamanho.

\begin{tabular}{|c|c|c|c|c|c|c|c|c|}
\hline \multirow{3}{*}{ Method } & \multicolumn{8}{|c|}{ Polygon size class } \\
\hline & \multicolumn{2}{|c|}{ (I) $<25$ ha } & \multicolumn{2}{|c|}{ (II) 25.01 a 100 ha } & \multicolumn{2}{|c|}{ (III) 100.01 a 1.600 ha } & \multicolumn{2}{|c|}{$(\mathrm{IV})>1,600 \mathrm{ha}$} \\
\hline & n & área (ha) & $\mathbf{n}$ & área (ha) & $\mathbf{n}$ & área (ha) & n & área (ha) \\
\hline Reference & 560 & $4.332,31$ & 179 & $8.949,30$ & 167 & $69.128,92$ & 10 & $45.940,97$ \\
\hline M1 & 2.460 & $5.036,14$ & 126 & $6.388,08$ & 105 & $40.717,81$ & 17 & $110.717,96$ \\
\hline M2 & 2.351 & $3.667,06$ & 89 & $4.535,22$ & 80 & $35.444,33$ & 15 & $107.821,45$ \\
\hline M3 & 3.705 & $6.713,15$ & 148 & $6.915,44$ & 116 & $43.959,25$ & 18 & $121.644,43$ \\
\hline M4 & 2.520 & $4.349,59$ & 101 & $5.093,95$ & 99 & $39.091,05$ & 17 & $110.741,39$ \\
\hline M5 & 3.222 & $5.656,14$ & 164 & $8.264,79$ & 125 & $48.617,75$ & 13 & $102.796,11$ \\
\hline M6 & 1.878 & $3.729,23$ & 106 & $5.445,99$ & 85 & $38.685,99$ & 14 & $106.727,42$ \\
\hline
\end{tabular}

FLORESTA, Curitiba, PR, v. 48, n. 4, p. 553-562, out/dez. 2018

Pereira. I. M. S. et.al.

ISSN eletrônico 1982-4688

DOI: $10.5380 /$ rf.v48i4.57362 
For all the methods tested, the greatest number of polygons was concentrated in class I (less than 25 ha), representing approximately $90 \%$ of the polygons identified. Meanwhile, in the reference data, polygons of the same class accounted for approximately $60 \%$ of the total. It was possible to observe an overestimation of the number of polygons in areas smaller than 25 ha. However, when compared to the area corresponding to the number of polygons in class I, it represents, on average, only $3 \%$ of the total area identified for both the methods and the reference. In the other size classes (II, III and IV), the number of polygons decreased as the area increased. The average number of polygons for these classes was 20, 18 and $1 \%$ for the reference polygons, and approximately 4, 4 and 1\% for the methods ones, respectively. Regarding the burned area, approximately 25 and $54 \%$ of the area obtained by both the methods tested and the reference, respectively, are in class III (between 100.00 and $1600 \mathrm{ha}$ ). In class IV, the reference methodology obtained $36 \%$ of the area, while the methods tested obtained, on average, $68 \%$.

In relation to the spectral behavior of the burned areas, the reflectance values of the polygons of burned area referring to the bands used in the index composition were extracted: band 4 (red), band 5 (near-infrared) and band 7 (short-wave infrared), before and after the fire, as shown in Figure 2.

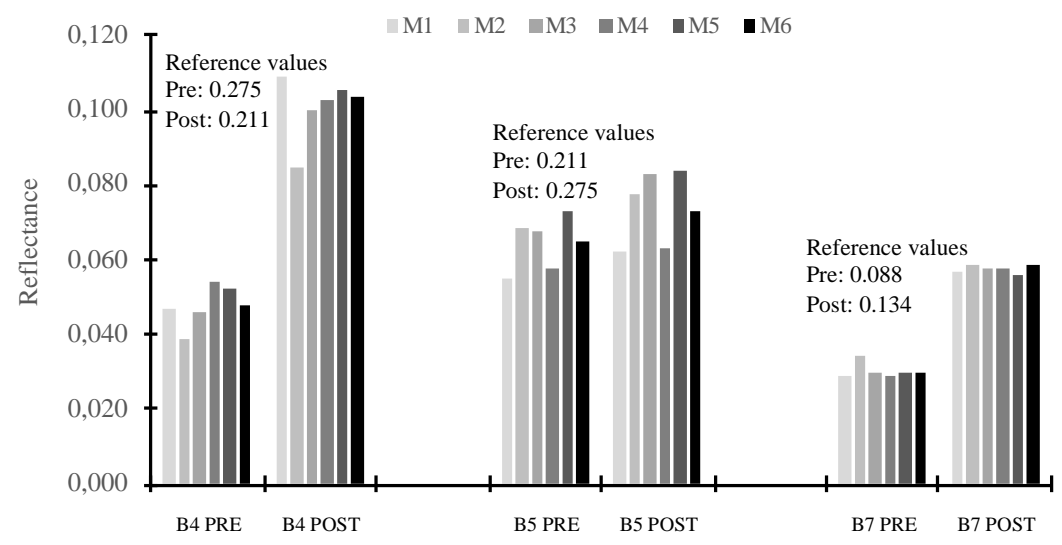

Figure 2. Reflectance values for bands 4 (red), 5 (near infrared) and 7 (short wave infrared), before and after fire.

Figura 2. Valores de reflectância para as bandas 4 (vermelho), 5 (infravermelho próximo) e 7 (infravermelho de ondas curtas), para antes e depois do fogo.

The largest variations between before and after the fire were found in bands $4(0.045-0.108)$ and 7 $(0.035-0.060)$, which showed a considerable increase in reflectance values obtained before and after the fire. Band 5 presented a smaller difference between the values of before and after the fire $(0.061-0.078)$. The reflectance values obtained by the methods tested were lower than the reference ones. This may have been caused by errors, since there were reflectance values that did not correspond to burned areas.

The burned area data obtained by the reference methodology were associated to the classes of land cover and use (Figure 3). As can be seen in Figure 3, the classes most affected by the fire were the rural formations, which include fields and the campo rupestre (approximately 48\%), followed by forest formations of Cerrado, which include gallery forest/ciliary forest and the Cerradão (approximately 18\%), and the Cerrado sensu stricto (7\%). Anthropogenic agricultural areas, which include agriculture and livestock, presented 5\% of burned areas, while the other classes presented values below $1 \%$. 


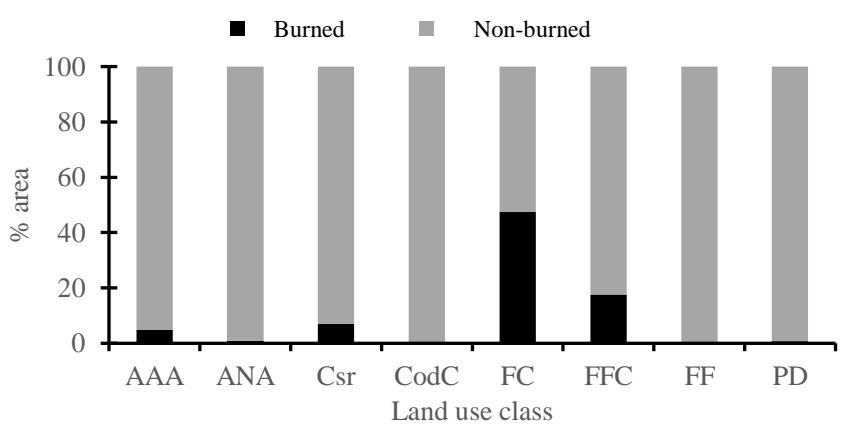

AAA: agriculture anthropic area; ANA: non-agriculture anthropic area Csr: Cerrado sensu stricto; CodC: water bodies; FC: rural formations; FF: forestry formations; FFC: forest formations of cerrado; PD: beach and dune.

Figure 3. Burned area distributed by classes of cover and land use.

Figura 3. Área queimada distribuída por classe de cobertura e uso do solo.

In addition to obtaining the burned area within the classes of cover and land use, the distribution of errors in relation to the classes can also be analyzed. This analysis makes it possible to understand in which classes the method underestimated (omission) and overestimated (commission), due to an eventual confusion of spectrum. In Table 3, these errors, distributed by class of land cover and use, can be observed for each method.

Table 3. Omission and commission errors of each method distributed according to the classes of land use.

Tabela 3. Erros de omissão e comissão de cada método distribuído de acordo com as classes de uso do solo.

\begin{tabular}{|c|c|c|c|c|c|c|c|c|c|c|c|c|}
\hline \multirow{3}{*}{$\begin{array}{c}\text { Land } \\
\text { use } \\
\text { class }\end{array}$} & \multicolumn{12}{|c|}{ Methods } \\
\hline & \multicolumn{2}{|c|}{ M1 } & \multicolumn{2}{|c|}{ M2 } & \multicolumn{2}{|c|}{ M3 } & \multicolumn{2}{|c|}{ M4 } & \multicolumn{2}{|c|}{ M5 } & \multicolumn{2}{|c|}{ M6 } \\
\hline & $\mathrm{CO}$ & OM & $\mathrm{CO}$ & OM & $\mathrm{CO}$ & OM & $\mathrm{CO}$ & OM & $\mathrm{CO}$ & OM & $\mathrm{CO}$ & OM \\
\hline AAA & 28,91 & 6,44 & 12,31 & 11,14 & 21,37 & 7,38 & 28,46 & 6,04 & 38,04 & 6,91 & 17,20 & 8,02 \\
\hline ANA & 0,05 & 0,03 & 0,13 & 0,02 & 0,05 & 0,03 & 0,03 & 0,02 & 0,03 & 0,01 & 0,04 & 0,00 \\
\hline Csr & 17,25 & 27,94 & 21,93 & 23,51 & 17,37 & 22,59 & 15,44 & 27,89 & 13,25 & 26,57 & 20,50 & 23,26 \\
\hline CodC & 0,69 & 0,06 & 0,18 & 0,07 & 0,27 & 0,07 & 0,51 & 0,05 & 0,63 & 0,04 & 0,56 & 0,08 \\
\hline $\mathrm{FC}$ & 44,17 & 36,72 & 46,86 & 50,06 & 51,03 & 48,44 & 47,39 & 36,21 & 42,61 & 25,80 & 49,61 & 45,92 \\
\hline FFC & 8,66 & 28,74 & 17,99 & 15,15 & 9,65 & 21,42 & 7,88 & 29,72 & 5,29 & 40,63 & 11,81 & 22,63 \\
\hline FF & 0,25 & 0,06 & 0,57 & 0,05 & 0,23 & 0,08 & 0,24 & 0,07 & 0,14 & 0,05 & 0,26 & 0,08 \\
\hline PD & 0,02 & 0,01 & 0,04 & 0,00 & 0,02 & 0,01 & 0,05 & 0,01 & 0,02 & 0,00 & 0,03 & 0,00 \\
\hline
\end{tabular}

Em que: M1: (R) dNBR (G) NBRpost (B) dNDVI; M2: (R) dNBR (G) NBRpost (B) dMSAVI; M3: (R) dNBR (G) NBRpost (B) dSAVI; M4: (R) dNBR (G) NBRpost (B) dGEMI; M5: (R) dNBR (G) NBRpost (B) dBAIMmod; M6: (R) dNBR (G) NBRpost (B) dMIRBImod; AAA: agriculture anthropic area; ANA: non-agriculture anthropic area Csr: Cerrado sensu stricto; CodC: water bodies; FC: rural formations; FF: forestry formations; FFC: forest formations of cerrado; PD: beach and dune.

Most commission errors were concentrated on rural formations, and were responsible for almost half of the overestimations (42.61 to 51.03\%). Following these errors, there are the ones in the anthropogenic agricultural areas (12.31 38.04\%) and in the Cerrado sensu stricto (13.25 to 21.93\%). The errors of omission were higher in rural formations (25.80 to 50.06\%), in Cerrado forest formations (15.15 to 29.72\%) and in Cerrado sensu stricto (22.59 to $27.94 \%)$.

\section{DISCUSSION}

The use of spectral indices on the identification of burned areas in the Cerrado region studied proved to be favorable and efficient. Although the Cerrado has a more widespread vegetation, spectral saturation was not a limiting factor, allowing the recognition of small differences in the relative amount of green biomass (STROPPIANA et al., 2012). Regarding the identification of burned areas, the methods tested proved to be similar. However, methods M6 and M2 presented higher values for both accuracy percentage and Kappa values. These methods may be considered efficient in the identification of burned areas in the studied region, and are considered excellent by Kaliraj et al. (2017).

The results obtained for M6, composed of the MIRBImod index, corroborate those of the study carried out by Stroppiana et al. (2012), in which the ability to reduce the confusion between burned areas and vegetation was observed. The result of M2, which used the dSAVI, is linked to the fact that this index includes an adjustment factor related to the direction of the soil line, ie to the soil reflectance regression line in the band 4 
(R) relation and band 5 (NIR) (QI et al., 1994). Veraverbeke et al. (2012) found that the SAVI outperformed the NDVI in environments with a single vegetation type, making it clear that this index attempts to minimize background variability. Another factor that contributed to the similarity between the methods and their good performance was the use of the indices dNBR and NBR in all compositions. Both stand out in comparison to other indices, since they essentially work with both the near-infrared and short-wave infrared bands. (PEREIRA et al., 2016; VERAVERBEKE et al., 2012).

In order to understand the spectral behavior of the fires, it is necessary to analyze the reflectance values of the spectral bands before (pre-fire) and after the fires (post-fire). It is then possible to identify in which bands there is a greater sensitivity in the spectral response of the areas affected by the fire. Generally, the burned areas present lower values in the visible spectrum. These values increase according to the shift to larger wavelengths, due to the physico-chemical characteristics of the burned vegetation and the contribution of the soil (PEREIRA et al., 2016).

The spectral indices are calculated based on the reflectance values of the orbital sensor bands. In this sense, the vegetation characteristics directly influence the temporal variations of these values. The pigments in the leaves are responsible for changes in the visible spectrum (PLENIOU; KOUTSIAS, 2013), since chlorophyll absorbs solar energy in the blue and red regions, especially on this range (ABRAHÃO et al., 2013). Thus, the green color is intensely reflected. In the present study, reflectance values in the red region (band 4) presented an increase after the fire, a fact also reported by Schepers et al. (2014). According to Toniol et al. (2017), the Cerrado vegetation presents values of reflectance higher than normal in the visible spectrum. This occurs due to the onset of leaf senescence (loss of water).

As for the near-infrared region (NIR), the values tend to decrease after the occurrence of a burn, since this range presents low absorption of solar energy by the leaves and, therefore, high reflectance (SCHEPERS et al., 2014; TONIOL et al., 2017). There are several studies in the literature that verify the decrease of this value in the NIR region after the event of fire in different types of vegetation (SCHEPERS et al., 2014; SANTOS et al., 2018). However, different results were found in a study carried out by Pereira et al. (2016). The authors observed an increase in the reflectance value in this channel in a Savanna region. This increase can be explained by the presence of dry soils and whitish colors (such as the neosols that predominate in the studied region), as well as by the scattering of the ashes due to the characteristic wind of the region (PEREIRA et al., 2016). In the present study, an increase in the reflectance values in band 5 (near-infrared) was observed. The difference, however, was subtle, corroborating the work of Pereira et al. (2016), which found a low variation in NIR values for the Jalapão region.

In the wavelength of the short-wave infrared (SWIR), reflectance is characterized by the presence of water on the leaf. Thus, the loss of the water contained in the tissues of the plants determines the increase of reflectance in this channel after a fire (TONIOL et al., 2017). Band 7 (short-wave infrared) presented an increase in the reflectance value. In the study carried out by Pereira et al. (2016), small changes in these values were identified with a subtle increase after the occurrence of a fire.

\section{CONCLUSIONS}

- The use of spectral indices presented a good performance in the identification of burned areas in the Cerrado region, with little difference among the methods tested.

- The spectral behavior of the burned areas in the red, near-infrared and short-wave infrared regions have characteristics that highlight the burned areas, and the combination of these characteristics is a way to obtain an even better result.

- The use of indices that combine near-infrared and short-wave infrared bands is the best way to identify burned areas.

\section{REFERENCES}

ABRAHÃO, S. A.; PINTO, F. A. C.; QUEIROZ, D. M.; SANTOS, N. T.; CARNEIRO, J. E. S. Determination of nitrogen and chlorophyll levels in bean-plant leaves by using spectral vegetation bands and indices. Revista Ciência Agrônomica, Fortaleza, v. 44, n. 3, p. 464-473, 2013.

BASTARRIKA, A.; CHUVIECO, E.; MARTIN, M. P. Mapping burned areas from Landsat TM/ETM+ data with a two-phase algorithm: Balancing omission and commission errors. Remote Sensing of Environment, Nova Iorque, v. 115, n. 4, p. 1003-1012, 2011. 
BASTARRIKA, A.; AlVARADO, M.; ARTANO, K.; MARTINEZ, M. P.; MESANZA, A.; TORRE, L.; RAMO, R.; CHUVIECO, E. BAMS: a tool for supervised burned area mapping using Landsat data. Remote Sensing, Basel, v. 6, n. 12, p. 12360-12380, 2014.

BOSCHETTI, M.; STROPPIANA, D.; BRIVIO, P. A. Mapping burned areas in a Mediterranean environment using soft integration of spectral indices from high resolution satellite images. Earth Interactions, Boston, v. 14, sn, p. 1-20, 2010.

CÂNDIDO, P. A. Mapeamento de cicatrizes de queimadas na região do Parque Estadual do Jalapão em 2007, 2008 e 2009. INPE. São José dos Campos, 2014.

CARVALHO-JÚNIOR, O. A.; GUIMARÃES, R; SILVA, C.; GOMES, R. Standardized time-series and interannual phenological deviation: new techniques for burned-area detection using long-term MODIS-NBR Dataset. Remote Sensing, Basel, v. 7, sn, p. 6950-6985, 2015.

CARVAlho, E. V.; BATISTA, A. C.; COElho, M. C.; NEVES, C. O. M.; SANTOS, G. R.; GIONGO, M. Caracterização de áreas queimadas no estado do Tocantins no ano de 2014. Floresta, Curitiba, v. 47, n. 3, p. 269-278, 2017.

GAROFAlO, T. D. F.; MESSIAS, C. G.; LIESENBERG, V.; BOLFE, E. L.; FERREIRA, M. C. Análise comparativa de classificadores digitais em imagens do Landsat 8 aplicados ao mapeamento temático. Revista Agropecuária Brasileira, Brasília, v. 50, n. 7, p. 593-604, 2015.

HEALEY, S. P.; COHEN, W. B.; YANG, Z.; BREWER, C. K.; BROOKS, E. B.; GORELICK, N.; HERNANDEZ, A. J.; HUANG, C.; HUGHES, M. J.; KENNEDY, R. E.; LOVELAND, T. R.; MOISEN, G. G.; SCHROEDER, T. A.; STEHMAN, S. V.; VOGELMANN, J. E.; WOODCOCK, C. E.; YANG, L.; ZHU, Z. Mapping forest change using stacked generalization: an ensemble approach. Remote Sensing of Environment, Nova Iorque, v. 204, sn, p.717-728, 2018.

KALIRAJ, S.; CHANDRASEKAR, N.; RAMACHANDRAN, K. K.; SRINIVAS, Y.; SARAVANAN, S. Costal landuse and land cover change and transformation of Kanyakumari coast, India using remote sensing and GIS. The Egyptian Journal of Remote Sensing and Space Science, Cairo, v. 20, n. 2, p. 169-185, 2017.

KUMAR, S. S.; ROY, D. P. Global operational land imager Landsat-8 reflectance-based active fire detection algorithm. International Journal of Digital Earth, Abingdon, v. 11, n. 2, p. 154-178, 2018.

LI, L.; XU, T.; CHEN, Y. Fuzzy classification of high resolution remote sensing scenes using visual attention features. Computational Intelligence and Neuroscience, Londres, v. 2017, p.1-9, 2017.

LHERMITTE, S.; VERBESSELT, J.; VERSTRAETEN, W.W.; VERAVERBEKE, S.; COPPIN, P. Assessing intra-annual vegetation regrowth after fire using the pixel based regeneration index. ISPRS Journal of Photogrammetry and Remote Sensing, Amsterdã, v. 66, n. 1, p. 17-27, 2011.

MOSES, W. J.; GITELSON, A. A.; PERK, R. L.; GURLIN, D.; RUNDIQUIST, D. C.; LEAVITT, B. C.; BARROW, T. M.; BRAKHAGE, P. Estimation of chlorophyll-a concentration in turbid productive waters using airbone hyperspectral data. Water Research, Kidlington, v. 46, n. 4, p. 993-1004, 2012.

NORTON, J.; GLENN, N.; GERMINO, K.; WEBER, M.; SEEFELDT, S. Relative suitability of indices derived from Landsat ETM+ and SPOT 5 for detecting fire severity in sagebrush steppe. International Journal of Applied Earth Observation and Geoinformation, Amsterdã, v. 11, n. 5, p. 360-367, 2009.

PEREIRA, A. A.; TEIXEIRA, F.; LIBONATI, R.; MELCHIORI, E.; CARVALHO, L. M. T. Avaliação de índices espectrais para identificação de áreas queimadas no Cerrado utilizando dados Landsat TM. Revista Brasileira de Cartografia, Rio de Janeiro, v. 68, n. 8, p. 1665-1680, 2016.

PLENIOU, M.; KOUTSIAS, N. Sensitivity of spectral reflectance values to different burn and vegetation ratios: A multi-scale approach applied in a fire affected area. ISPRS Journal of Photogrammetry and Remote Sensing, Amsterdã, v. 79, sn, p. 199-210, 2013.

QI, J.; CHEHBOUNIDI, A.; HUETE, A.; KERR, Y.; SOROOSHIAN, S. A modified soil adjusted vegetation index. Remote Sensing of Environment, Nova Iorque, v. 48, n. 2, p. 119-126, 1994.

SANTOS, J. F.; ROMEIRA, J. M. N.; ASSIS, J. B.; TORRES, F. T. P.; GLERIANI, J. M. Potentials and limitations of remote fire monitoring in protected area. Science of the Total Environment, Amsterdã, v. 616617, sn, p. 1347-1355, 2018. 
SCHEPERS, L.; HAEST, B.; VERAVERBEKE, S.; SPANHOVE, T.; BORRE, J. V.; GOOSSENS R. Burned area detection and burn severity assessment of a heathland fire in Belgium usind airbone imagin spectroscopy (APEX). Remote sensing, v. 6, n. 3, p. 1803-1826, 2014.

STROPPIANA, D.; BORDOGNA, G.; CARRARA, P.; BOSCHETTI, M.; BOSCHETTI, L.; BRIVIO, P. A. A method for extracting burned areas from Landsat TM/ETM+ images by soft aggregation of multiple Spectral Indices and a region growing algorithm. ISPRS Journal of Photogrammetry and Remote Sensing, Amsterdã, v. 69, sn, p. 88-102, 2012.

TONIOL, A. C.; GALVÃO, L. S.; PONZONI, F. J.; SANO, E. E.; AMORE, D. J. Pontetial of hyperspectral metrics and classifiers for mapping Brazilian savannas in the rainy and dry seasons. Remote Sensing Applications: Society and Environment, Amsterdã, v. 8, sn, p.20-29, 2017.

VERAVERBEKE, S., HOOK, S., HULLEY, G. An alternative spectral index for rapid fire severity assessments. Remote Sensing of Environment, Nova Iorque, v. 123, sn, p. 72-80, 2012.

XUE, J.; SU, B. Significant remote sensing vegetation indices: a review of developments and application. Journal of Sensors, Londres, v. 2017, sn, p.1-17, 2017. 